\title{
Growth Indices and Grain Yield Attributes in Six Maize Cultivars Representing Two Era of Maize Breeding in Nigeria
}

\author{
Folusho Anuoluwapo Adebo \\ Department of Agronomy, University of Ilorin \\ P.M.B 1515, Ilorin, Nigeria \\ Tel: 234-805-328-2109_E-mail: jadesolaoluwa@yahoo.com \\ G. Olaoye (Corresponding author) \\ Department of Agronomy, University of Ilorin \\ P.M.B 1515, Ilorin, Nigeria \\ Tel: 234-803-585-0557Ｅ-mail: debolaoye@yahoo.com
}

\begin{abstract}
Growth parameters such as seedling germination attributes, crop growth rate (CGR), relative growth rate (RGR), net assimilation rate (NAR) and leaf area ratio (LAR) as well as yield parameters were investigated in six maize cultivars representing two era of maize breeding in Nigeria during the 2005 late and 2006 early cropping seasons. Differences between maize breeding era were significant for seedling emergence (E \%) and emergence index (EI) while genotypes within a particular breeding era $(\mathrm{G} / \mathrm{E})$ differed significantly for $\mathrm{E} \%$ and emergence rate index (ERI). Seasonal (S) variation in seedling parameters was also significant for E \% and ERI with a $15 \%$ higher seedling emergence in 2006 early season. CGR in the genotypes in breeding era 1 was higher by seven percent (7\%) during vegetative growth phase but lower by $14 \%$ at flowering phase compared to genotypes in breeding era 2. NAR on the other hand was consistently higher in varieties developed in 1970's by 15.2 and $13.8 \%$ compared to varieties developed in 1990's. Regardless of the breeding era, varieties with higher values for LAR at flowering (except var. TZPB-SR) were higher yielding than those with lower LAR. Overall, varieties developed in era 2 were superior to those developed in era 1 for E\% and also had six percent (6\%) higher values for LAR at vegetative growth phase than those developed in era 1 but decreased by two percent $(2 \%)$ at flowering phase. E\% in the genotypes ranged from 48.56 in ACR 9943 DMRSR to 79.33 in ACR99TZL COMP4 DMRSR, while EI and ERI ranged from 0.86 and 0.010 in TZB-SR to 0.96 and 0.014 in ACR 97 TZL COMP1-W. Grain yield was significantly higher in 2006 early cropping season by $0.3 \mathrm{t} / \mathrm{ha}^{-1}$ translating to $14.78 \%$ than in late season and it ranged from $1.64 \mathrm{t} / \mathrm{ha}^{-1}$ in TZPB-SR (era 1) to 2.94t/ha $\mathrm{h}^{-1}$ in ACR99TZLCOMP4DMRSR (era 2). Var. ACR99TZL COMP4DMRSR with the lowest values for CGR, RGR and NAR at vegetative phase had the highest grain yield $\left(2.94 \mathrm{t} / \mathrm{ha}^{-1}\right)$ indicating that genotypic superiority for grain yield is not particularly related to differences in any of these traits but rather dependent on the inherent genetic potential of the varieties themselves.
\end{abstract}

Keywords: Zea mays L., Growth indices, Maize breeding era, Grain yield

\section{Introduction}

Maize improvement for grain yield potential, stability of yield including plant and grain characteristics have gone through several stages in Nigeria since 1950. The breeding efforts which began with the introgression of genes for pest and disease resistance (Fajemisin, 1985; Fakorede et al., 1993; 2001) to the development of maize genotypes (open pollinated varieties and hybrids) with high grain yield potential (Kim et al., 1993) as well as adaptation to different ecologies and stress factors (Kim, 1997), have resulted in the development and release of productive maize varieties for different agro-ecologies in Nigeria. Initial gains in grain yield by 1962 was estimated at between 1.5 and $2.5 \mathrm{t} / \mathrm{ha}^{-1}$ or $(43.71 \%$ ) giving approximately 1.4 to $2.4 \%$ gains per annum (Fakorede et al. 1993). Introduction of high yielding open pollinated varieties (OPVs) and hybrids into the Nigeria's savanna between 1985 and 1990 resulted in further yield increase ranging from $4.25 \mathrm{t} / \mathrm{ha}^{-1}$ to $5.15 \mathrm{t} / \mathrm{ha}^{-1}$, representing an average of $22 \%$ yield advantage especially for the hybrids (Kim et al., 1993). Maize grain yield since then has witnessed a phenomena increase as high as $14.7 \mathrm{t} / \mathrm{ha}^{-1}$ in high yielding environments of the West and Central Africa (WCA) representing 20 to $40 \%$ yield advantage (Kim, 1997). In a recent study which compared the performance of maize OPVs developed for WCA between 1970 and 1999 across the West African savannas, Kamara et al., (2004) also reported genetic gain in grain yield of $0 \cdot 41 \%$ per year ${ }^{-1}$. 
Underlying the reported gains in grain yield, is the improvement in characters such as tolerance to plant population density stress, nitrogen $(\mathrm{N})$ stress, cold temperature stress, water stress and weed competition (Castleberry et al., 1984; Duvick, 1997; Tollenaar et al., 1994b, 1997, 2000; Tollenaar and Wu, 1999; Ying et al., 2000; Edmeades et al., 2006; Campos et al., 2006). Lee and Tollenaar, (2007) also noted that changes in light interception due to increased leaf area index (LAI) and in light utilization due to more erect upper leaves, maintenance of green leaf area and leaf photosynthesis during grain filling period, resulted in significant increase in dry matter accumulation (DMA) of up to $113 \%$ in ERA-hybrid grain yield in the USA. Other attributes that have contributed to gains in grain yield of newer generation of maize cultivars are kernel number (Tollenaar et al., 1992) and greater partitioning of dry matter to the kernels during the sensitive period of kernel establishment (Echarte et al., 2004; Echarte and Tollenaar, 2006).

However as plant breeding efforts result in emergence of newer varieties with increased productivity and better adaptation to diverse ecosystems as well as increased resistance/tolerance to biotic and abiotic stress factors and changing farming practices, so also is the possibility of changes in growth parameters which may be morphological, physiological or a combination of both. In other words, the gains in grain yield attributable to maize breeding in Nigeria (Kamara et al., 2004), may also have been accompanied by changes including seedling emergence, early growth characteristics and other morpho-physiological characteristics.

Growth is a vital function of plants and is an indication of a gradual increase in number and size of cells. Growth parameters such as germination, leaf area index, relative growth rate and net assimilation rate are very important in assessing crop growth and may be an indication of potential productivity especially since cultivars having balanced vegetative growth under stress leads to better economic returns (Khan et al., 2005). The authors further noted that genetic diversity for growth between and within crop species gives economic stability and permits the choice of crops and their cultivars that are adapted for a region or for the specific field conditions. This study was therefore designed to assess relative performance of six varieties representing two era of maize breeding in Nigeria and to investigate possible changes which may have occurred in seedling emergence, crop growth and grain yield characteristics between the two era of maize breeding in Nigeria.

\section{Materials and methods}

\subsection{Description of Genetic Materials}

The materials used which comprised six late maturing maize cultivars were obtained from the International Institute of Tropical Agriculture (IITA). Ibadan, Nigeria. Three of the varieties (TZPB-SR, TZB-SR and ACR9943-DMRSR) were developed in the 1970's while the other three (ACR96 DMR LSRW, ACR 97 TZL COMP1-W and ACR99TZL COMP4DMRSR) were developed in 1990's. The six varieties are all late maturing, white grained type with endosperm attributes ranging from Dent, Flint or Dent/flint.

\subsection{Experimentation}

The genetic materials were evaluated during the 2005 late and 2006 early-cropping seasons at the Teaching and Research ( $\mathrm{T} \& \mathrm{R}$ ) farm, University of Ilorin in the Southern guinea Savanna Zone (SGSZ) of Nigeria. Ilorin is in the Southern Guinea Savanna ecology (Lat $8^{\circ} 29^{\prime} \mathrm{N} \&$ Long $4^{\circ} 24^{\prime} \mathrm{E}, 370 \mathrm{~mm}$ above the sea level) of Nigeria. Rainfall distribution in the location is bimodal with annual rainfall of $1100-1400 \mathrm{~mm}$. However, the distribution is highly unpredictable, usually with false start around April which may stop abruptly few weeks after and ending not later than mid-October of every year. The trials were established on August 6, 2005 and May 23, 2006 respectively. The trials were laid out each season in a randomized complete block design (RCBD) with four replications and at a planting distance of $0.75 \mathrm{~m}$ between the rows and $0.5 \mathrm{~m}$ within the rows. Each plot was six rows and the outer rows were used for destructive sampling, while observations were taken from the four middle rows.

Seeds were treated with apron plus before planting for protection against seed borne diseases and soil borne pests. Three seeds were planted/hill but later thinned to two/hill two weeks after planting (WAP). Agronomic practices included pre-emergence application of herbicide (stomp and atrazine) to control weeds at the rate of $100 \mathrm{ml}$ to 20liters of water, supplemented by hoe weeding as necessary. Compound fertilizer (NPK 20:10:10) was applied as split-dosage at the rate of $80 \mathrm{kgN} / \mathrm{ha}, 40 \mathrm{~K}_{2} \mathrm{O} /$ ha and $40 \mathrm{P}_{2} \mathrm{O}_{5} 3 \mathrm{WAP}$ and at anthesis (7WAP), using the side placement method.

\subsection{Data Collection and Analyses}

Data were collected from the four central rows on seedling emergence and growth characteristics as well as grain yield and yield components. Seedling emergence was collected on 5, 7 and nine (9) days after planting (DAP) respectively. Leaf area measurements were also taken at 2, 4,6 and 8 weeks after planting (WAP). At each of 
these periods, fresh plant parts (root, stem and leaf) obtained from ten plants/plot were weighed in the laboratory and later dried to a constant weight in the oven at $80^{\circ} \mathrm{C}$.

\subsubsection{Seedling emergence traits}

Data on seedling emergence were used to compute emergence percentage (E \%), emergence index (EI) and emergence rate index (ERI) respectively.

E $\%$ was computed as 100 [Number of seedlings emerged 9DAP]/ Total number of seeds planted

EI was computed as described by Fakorede and Ojo (1981)

$\mathrm{EI}=\sum[(\mathrm{Nx})(\mathrm{DAP}) /$ Seedlings emerged 9DAP $]$.

$\mathrm{ERI}=\mathrm{EI} / \mathrm{E} \%$.

$\mathrm{Nx}$ is the number of seedlings emerged on day $\mathrm{x}$

\subsubsection{Growth parameters}

Values obtained from the periodic measurements were then used to compute physiological parameters of relative growth rate (RGR), net assimilation rate (NAR) and leaf area ratio (LAR) using the following formulae proposed by Gardner et al. (1985).

Crop Growth Rate (CGR) was computed in $\mathrm{gm}^{-2} \mathrm{~d}^{-1}$ using the formula

$\mathrm{CGR}=\left[\mathrm{W}_{2}-\mathrm{W}_{1} / \mathrm{T}_{2}-\mathrm{T}_{1}\right]$.

Relative Growth Rate (RGR) was computed in $\mathrm{gkg}^{-1} / \mathrm{d}^{-1}$ from the oven dried weight of samples between 4,6 and $8 \mathrm{WAP}$ as

$\mathrm{RGR}=\left[1 \mathrm{nW}_{2}-\ln \mathrm{W}_{1} / \mathrm{T}_{2}-\mathrm{T}_{1}\right]$.

Net Assimilation Rate (NAR) was computed in $\mathrm{gm}^{2} \mathrm{~d}^{-1}$ from the dry weight and leaf area at specified intervals as

$\mathrm{NAR}=\left[\left(\mathrm{W}_{2}-\mathrm{W}_{1}\right)\left(\operatorname{In~}_{2}-\operatorname{InA}_{1}\right) /\left(\mathrm{A}_{2}-\mathrm{A}_{1}\right)\left(1 \mathrm{nW}_{2}-1 \mathrm{n} \mathrm{W}_{1}\right)\right]$

Leaf Area Ratio (LAR) was also computed in $\mathrm{m}^{2} / \mathrm{kg}$ - this was computed as

$\mathrm{LAR}=\left[\left(\mathrm{A}_{2}-\mathrm{A}_{1}\right)\left(1 \mathrm{nW}_{2}-\operatorname{lnW_{1}}\right) /\left(\mathrm{W}_{2}-\mathrm{W}_{1}\right)\left(1 \mathrm{nA}_{2}-\ln \mathrm{A}_{1}\right)\right]$.

Where $\mathrm{A}_{1}=$ Initial leaf area

$$
\begin{aligned}
& \mathrm{A}_{2}=\text { Final leaf area } \\
& \mathrm{W}_{1}=\text { Initial dry weight } \\
& \mathrm{W}_{2}=\text { Final dry weight }
\end{aligned}
$$

$\ln =$ Natural logarithm

$\mathrm{T}_{2}-\mathrm{T}_{1}=$ Time interval between two harvests

\subsubsection{Agronomic and yield parameters}

Data were also collected on days to anthesis (pollen shed) and silking, plant and ear heights $(\mathrm{cm})$ and tassel branch number. Anthesis-silking- interval was computed as the difference between dates of silking and pollen shed. Plant and ear heights were measured as the distance $(\mathrm{cm})$ from the base of the plant to the height of the first tassel branch and the node bearing the upper ear, respectively. Ear aspect was rated visually on a scale of 1 to 5 where $1=$ clean, uniform, large and well-filled ears and $5=$ rotten, variable, small and partially filled ears. All ears harvested from each plot were weighed to determine grain yield per plot (assuming $80 \%$ shelling percentage) and was later converted to tones per ha $\left(\mathrm{t} / \mathrm{ha}^{-}{ }^{1}\right)$ after adjusting to $12 \%$ moisture content. 300 grain-samples were collected from each plot at harvest for the determination of harvest moisture. The samples were first weighed to obtain initial weight followed by drying to a constant weight in the oven at $80^{\circ} \mathrm{C}$ in the laboratory and the difference between the two weights recorded as moisture at harvest. Additional data were also collected on yield components viz: cob length $(\mathrm{cm})$ cob diameter $(\mathrm{cm})$, kernel row number, kernel depth $(\mathrm{cm})$ and 300 kernel weight (gm).

\subsection{Statistical analyses}

Data collected and estimated were subject to analyses of variance (ANOVA) first on individual season basis before combined ANOVA over seasons using the SAS GLM Proc (SAS Inst. Inc., 1997) based on a randomized complete block design and a model in which genotypes in each trial were considered fixed effects and seasons as 
random. Pertinent means were thereafter separated by means of Duncan Multiple Range Test (Steel and Torrie, 1980).

\section{Results}

\subsection{Seedling emergence characteristics}

Seasonal (S) variation was significant for emergence percentage (E \%) and emergence rate index (ERI) but not for emergence index (EI) which is a measure of speed of emergence (Table 1). Differences between breeding era (E) were also significant for E\% and EI but not for ERI. Genotypes within a particular breeding era (G/E) differed significantly for E\% and ERI but not for EI. However, the interactive effect of season by era (S x E) was significant only for $\mathrm{E} \%$ while $\mathrm{S} \times \mathrm{G} / \mathrm{E}$ interaction was not significant for any of the seedling emergence traits. Differences between seasons for EI and ERI were 0.03 and 0.012 respectively with the value obtained for ERI in 2006 early season significantly higher than for 2005 late season. E\% and EI were also better for varieties developed in 1990's than those developed in 1970's.

Varieties developed in 1990's generally showed superiority for seedling emergence compared with those developed in 1970's but did not differ in speed of emergence (Table 2). E\% ranged from 48.56 in ACR 9943 DMRSR to 79.33 in ACR99TZL COMP4 DMRSR, while EI and ERI ranged from 0.86 and 0.010 in TZB-SR to 0.96 and 0.014 in ACR 97 TZL COMP1-W. One variety in each era of breeding (ACR 9943DMRSR and ACR96 DMR LSRW) had significantly lower E\% than others within their respective groups, consequently higher ERI values. Varieties developed in 1990's also emerged faster (EI) than those developed in 1970's. Var. ACR99TZL COMP4 DMRSR with the highest E\% also had the highest EI suggesting superiority of this variety for seedling emergence characteristics.

\subsection{Physiological attributes}

Seasonal effects were significant for all the physiological attributes except net assimilation rate (NAR) during the growth phase which coincided with flowering (Table 3). However, the two breeding era differed significant only for leaf area ratio (LAR) during the vegetative phase and for crop growth rate (CGR) during flowering. Differences between genotypes within a breeding era were significant for relative growth rate (RGR) during flowering phase and NAR at the vegetative growth phase. $\mathrm{S} \times \mathrm{E}$ interactive effects were significant also for RGR and NAR during the flowering phase while $\mathrm{S} \times \mathrm{G} / \mathrm{E}$ interaction was not significant for any of the physiological attributes. CGR was better in 2005 late season than in 2006 early season while the reverse was the case for other physiological parameters (RGR, NAR and LAR). Higher values were recorded for CGR in 2005 late season compared to 2006 early season. Conversely, RGR during the active flowering stage was better in 2006 early cropping season than in 2005 late cropping season. NAR was also significantly higher during the vegetative phase with values obtained in the late season higher than that for early cropping season. Values for LAR were higher in 2006 early season regardless of the sampling period but values obtained in respect of breeding eras differed with varieties developed in 1990's having a significantly higher LAR than those developed in 1970's.

The genotypes differed significantly for CGR, RGR and LAR respectively but not for NAR (Table 4). CGR and NAR in the genotypes increased with sampling time while RGR and LAR decreased with sampling time. Differences between breeding era for physiological attributes were not consistent. For example, CGR in the genotypes was higher by seven percent (7\%) during vegetative growth phase in breeding era 1 relative to era 2 but lower by $14 \%$ at flowering. NAR on the other hand was consistently higher by 15.2 and $13.8 \%$ in varieties developed in 1970's when compared with those developed in 1990's. Varieties developed in 1990's however had six percent $(6 \%)$ higher values for LAR at vegetative growth phase than those developed in era 1 but decreased by two percent $(2 \%)$ at flowering phase. Comparison between varieties for CGR revealed that genotypes with the lowest and highest values (TZB-SR and ACR9943DMRSR) were from breeding era 1. Var. ACR9943DMRSR also had the highest value for RGR at the vegetative phase although the value was only significantly higher than that of var. ACR99TZLCOMP4DMRSR. Although the varieties were similar for LAR at the vegetative growth phase, Vars. ACR 9943DMRSR (era 1) and ACR97TZLCOMP1-W (era 2) had the least values for this parameter.

\subsection{Grain yield and associated traits}

Effects of cropping seasons was significant for days to flowering, grain yield as well as yield components of 300 kernel weight, kernel depth and kernel row number respectively (Table 5). Differences between era of maize breeding were significant also for days to anthesis and kernel depth while difference between genotypes within a particular breeding era (G/E) was significant only for grain yield. However, the interactive effects of S X E and S $x \mathrm{G} / \mathrm{E}$ were not significant for any of the parameters. Grain yield was significantly higher in the early cropping 
season than in late season by $0.3 \mathrm{t} / \mathrm{ha}^{-1}$ translating to $14.78 \%$ increase over the late cropping season. Although differences in grain yield between maize breeding era was not significant, varieties developed in 1990's had a yield advantage of $0.55 \mathrm{t} / \mathrm{ha}^{-1}$ over those developed in 1970's which translated to $23.4 \%$ gain/era.

The genotypes differed significant for grain yield and associated traits except anthesis-silking-interval (Table 6). Ranges in the means for the genotypes were $11 \mathrm{~cm}, 815.1 \mathrm{gm}$ and $1.23 \mathrm{~cm}$ for ear placement, tassel branch number, kernel weight and kernel depth respectively. Grain yield also ranged from $1.64 \mathrm{t} / \mathrm{ha}^{-1}$ in TZPB-SR (era 1) to $2.94 \mathrm{t} / \mathrm{ha}^{-1}$ in ACR99TZLCOMP4DMRSR (era 2). Varieties developed in 1970's were generally taller than those developed in 1990's with corresponding higher values for tassel branch number (8) and yield components especially kernel weight $(15.06 \mathrm{~g})$ and kernel depth $(1.23 \mathrm{~cm})$ respectively. Var. ACR9943DMRSR showed superiority for almost all the traits associated with grain yield except kernel weight but was the second lowest yielding variety. Conversely, the highest yielding variety (ACR99TZLCOMP4DMRSR) had lower values for these parameters including ear placement. Vars. TZB-SR and ACR 97 TZLCOMP1-W were superior for KRN and significantly different from TZPB-SR. ACR 97 TZLCOMP1-W had the highest grain yield followed closely by vars. TZPB-SR and ACR 9943DMRSR in that order. Differences between the three varieties were however not significant but both vars. ACR 99TZL COMP1-W and TZB-SR differed significantly from the other three varieties for grain yield.

\section{Discussion}

\subsection{Seedling emergence characteristics}

Seedling emergence and early growth characteristics were better in 2006 early cropping season due to favourable climatic conditions particularly moisture which was adequate compared to the 2005 late cropping season characterized by sudden cessation of rains shortly after planting. This resulted in $15 \%$ higher seedling emergence with corresponding lower ERI value in 2006 early season. Earlier studies (Khan et al., 2005; Valero et al., 2005) have also shown that favourable environmental conditions and adequate availability of essential elements have a positive influence on seedling establishment and growth of crops.

\subsection{Physiological attributes}

Seasonal effects also had significant effects on almost all the physiological attributes except net assimilation rate (NAR) during the growth phase that coincided with flowering. Samarraic, (1990) as well as Zalba and Peinemann (1998) noted that CGR do vary with incident solar irradiance. In this study, higher values recorded for CGR which is the accumulation of dry matter per day in 2005 late season compared to 2006 early season was probably due to better insolation and lower incidence of biotic stress factors. Conversely, RGR which is the rate of dry matter production per gram of total dry weight per day especially during the active flowering stage was better in 2006 early cropping season than in 2005 late cropping season. This was probably due to availability of moisture in the early season as opposed to disruption in rains at different periods during the 2005 late cropping season. However, regardless of the cropping season, the lowest crop growth rate (CGR) values were recorded during early vegetative growth stages but increased to maximum during the flowering stage which is similar to the reports of other workers (Awal and Khan, 2000; Valero et al., 2005).

NAR is a measure of the rate of dry matter accumulation per unit leaf area. This attribute was also significantly higher during the vegetative phase with values obtained in the late season higher than that for early cropping season. Low NAR might be due to restricted availability of essential nutrients, decreased photosynthetic efficiency (Datta, 1994) or lower rate of biomass production (Khan et al., 2005). Although Valero et al., (2005) reported higher values for NAR during early vegetative growth but a decline during the latter stages, a situation which the authors attributed to a general decline in photosynthetic efficiency with leaf age and also perhaps to lack of nutrients in later stages, our results revealed that NAR values were higher during vegetative phase than at flowering phase. The difference between the two studies might be due to the fact that the authors extended their sampling till harvest time while we stopped sampling at flowering.

Increase in LAR and consequently increase in rate of dry matter accumulation, is proportional to rate of dry matter accumulation per unit leaf area (NAR). However, values recorded for vegetative growth phase in this study were significantly higher than values obtained for flowering phase. Soldati et al., (1984) reported that an increase in dry matter accumulation leads to an increase in leaf area because proportion of dry matter allocated to leaves remain fairly constant while an increase in leaf area leads to an increase in rate of dry matter accumulation because light interception is directly related to leaf area during this phase of development. Our results however showed an inverse relationship between LAR and either CGR or RGR during the different cropping seasons or genotypes between the two eras of maize breeding. 


\subsection{Grain yield}

An increase in NAR during the growing season is indicative of response of the photosynthetic apparatus to an increase in demand for assimilates to afford rapid growth of the grain fraction (Valero et al., 2005). In our study, we observed that superiority of the varieties for any of the physiological attributes did not translate to concomitant increase in grain yield. For example, Var. ACR 9943DMRSR with the highest values for CGR at both vegetative and flowering growth phases was also one of the varieties with the highest value for RGR at vegetative phase but recorded one of the lowest grain yield. Conversely var. ACR99TZL COMP4DMRSR with the highest grain yield had the lowest values for CGR, RGR and NAR at vegetative phase. However, previous studies (Crosbie 1982; Duvick, 1997; Tollenaar et al., 1994a; Tollenaar and Lee, 2002; Duvick, 2005) have also shown that increase in ERA-hybrid grain yield in the USA can be attributable to changes in light interception due to increased LAI and changes in light utilization due to more erect upper leaves, maintenance of green leaf area and leaf photosynthesis during the grain filling period rather than yield per plant and harvest index. In our study, varieties with higher values for LAR at flowering (except var. TZPB-SR) were higher yielding than those with lower values regardless of the era of breeding. In other words, genotypic superiority for grain yield is not particularly related to differences in any of these traits but rather dependent on the inherent genetic potential of the varieties themselves.

\section{References}

Awal, M. A., \& Khan, M.A.H. (2000). Mulch Induced Eco-physiological growth and Yield of maize. Pakistan Journal of Biological Sciences, 3 (1): 61-64.

Campos, H., Cooper, M., Edmeades, G.O., Löffler, C., Schussler, J.R., \& Ibañez, M. (2006). Changes in drought tolerance in maize associated with fifty years of breeding for yield in the U.S. corn belt. Maydica, 51:369-381.

Castleberry, R.M., Crum, C.W., \& Krull, C.F. (1984). Genetic yield improvement of US maize cultivars under varying fertility and climatic environments. Crop Sci., 24:33-36.

Crosbie, T.M. (1982). Changes in physiological traits associated with long-term breeding efforts to improve grain yield of maize. p. 206-233. In H.D. Loden and D. Wilkinson (ed.) Proc. Annu. Corn and Sorghum Ind. Res. Conf., 37th. Chicago, IL. 5-9 Dec. 1982. Am. Seed Trade Assoc., Washington, D.C.

Datta, S.C. (1994). Plant Physiology. Wiley Eastern Ltd. New Age Intl. Ltd. New Delhi, India.

Duvick, D.N. (1997). What is yield? p. 332-335 In G.O. Edmeades et al. (ed.) Developing drought and low N-tolerant maize. Proceedings of a Symposium, CIMMYT, El Batan, Mexico. 25-29 March 1996. CIMMYT, México, D.F.

Duvick, D.N. (2005). The contribution of breeding to yield advances in maize (Zea mays L.). Adv. Agron., 86:83-145.

Echarte, L., \& Tollenaar, M. (2006). Kernel set in maize hybrids and their inbred lines exposed to stress. Crop Sci., 46:870-878.

Echarte, L., Andrade, F.H., Vega, C.R.C., \& Tollenaar, M. (2004). Kernel number determination in Argentinean maize hybrids released between 1965 and 1993. Crop Sci., 44:1654-1661.

Edmeades, G.O., Bänziger, M., Campos, H., \& Schussler, J. (2006). Improving tolerance to abiotic stresses in staple crops: A random or planned process. p. 293-309 In K.R. Lamkey and M. Lee (ed.) Plant breeding: The Arnel R. Hallauer international symposium. Blackwell Publ., Oxford, UK.

Fakorede, M.A.B., \& Ojo, D.K. (1981). Variability for seedling vigour in maize. Exptal. Agric., 17: $195-201$.

Fakorede, M.A.B., Fajemisin, J.M., Ladipo, J.L., Ajala, S.O., \& Kim, S.K. (1993). Maize improvement in Nigeria. Past, present and future. P.15-40 in Fakorede, M.A.B., C.O. Alofe and S.K. Kim (eds.). Maize improvement, production and utilization in Nigeria. Maize Association of Nigeria Publication.

Fakorede, M.A.B., Fajemisin, J.M., Ladipo, J.L., Ajala, S.O., \& Kim, S.K. (2001). Development and regional deployment of streak virus maize germplasm: an overview. 503-516 in Jacqueline d'A Hughes and Babajide O Odu (eds). Plant Virology in Sub-Saharan Africa. Proc. of a conference organized by the International Institute of Tropical Agriculture, Ibadan $4^{\text {th }}-8^{\text {th }}$ June, 2001.

Fajemisin, J.M. (1985). Maize diseases in Africa and their role in varietal improvement process. Paper presented at the Maize Regional Workshop for Eastern ands Southern Africa held at Lusaka, Zambia. March 10-17, 1985.

Gardner, F.P., Pearce, R.B. \& Mitchell, R.L. (1985). Physiology of Crop Pants, pp. 187-208. Iowa State University Press. 
Kamara,A. Y., Menkir, A., Fakorede, M.A.B., Ajala, S.O, Badu-Apraku, B. \& Kureh, I. (2004). Agronomic performance of maize cultivars representing three decades of breeding in the Guinea Savannas of West and central Africa. The Journal of Agricultural Science, 142:5:567-575.

Khan, M. A., Abid, M., Hussain, N., \& Imran, T. (2005). Growth and analysis of wheat (Triticum aestivium L.) cultivars under saline conditions. International Journal of Agriculture and Biology, 2005 Vol. 7, No. 3, 508-510.

Kim, S.K. (1997). Achievements, challenges and future direction of hybrid maize research and production in West and Centrall Africa. P42-82. in B. Badu-Apraku, M.O. Akoroda, M. Ouedrago and F.M. Quin (eds.). Contributing to food self sufficiency in maize research and development in West and Xentral Africa. Proc. of a regional maize workshop, 29 may-2 June 1995, IITA Cotonou, Benin Republic.

Kim, S.K., Fajemisin, J.M., Fakorede, M.A.B., \& Iken, J.E. (1993). Maize improvement in Nigeria-Hybrid performance in the savanna zone. P. 41-46. Fakorede, M.A.B., C.O. Alofe and S.K. Kim (eds.). Maize improvement, production and utilization in Nigeria. Maize Association of Nigeria Publication.

Lee, E. A., \& Tollenaar, M. (2007). Physiological Basis of Successful Breeding Strategies for Maize Grain Yield. Crop Sci., 47:202-215.

SAS Institute. (1997). SAS/STAT software: Changes and enhancement through release 6.12. SAS Inst.,Cary, $\mathrm{NC}$.

Samarraic, S.M., Osman, H.E., Mian, H.R., Simsaa, O.E., \& Alami, M.S. (1990). Shade Effects on growth and biomass production of corn and sunflower in Western Saudi Arabia. King Saud Univ., Vol. 2, Agrie. Sci., (1), pp 51-59.

Soldati, A., Stehli, A. \& Stamp, P. (1984). Temperature adaptation of tropical highland maize (Zea mays L.) during early growth and in controlled conditions. Crop Sci., 24:28-32.

Steel, R.G.D., \& Torrie, J.H. (1980). Principles and Procedures of Statistics. A Biometrical Approach. $2^{\text {nd }}$ Edition. Mc Graw Hill Book Inc, New York. 1980, 580pp.

Tollenaar, M., \& Wu, J. (1999). Yield improvement in maize is attributable to greater stress tolerance. Crop Sci., 39:1597-1604.

Tollenaar, M., \& Lee, E.A. (2002). Yield potential yield, yield stability and stress tolerance in maize. Field Crops Res., 75:161-170.

Tollenaar, M., Aguilera, A., \& Nissanka, S.P. (1997). Grain yield is reduced more by weed interference in an old than in a new maize hybrid. Agron. J., 89:239-246.

Tollenaar, M., Ahmadzadeh, A., \& Lee, E.A. (2004). Physiological basis of heterosis for grain yield improvement in maize. Crop Sci., 44:2086-2094.

Tollenaar, M., Dwyer, L.M., \& Stewart, D.W. (1992). Ear and kernel formation in maize hybrids representing three decades of grain yield improvement in Ontario. Crop Sci., 32:432-438.

Tollenaar, M., McCullough, D.E., \& Dwyer, L.M.. (1994a). Physiological basis of the genetic improvement of corn. p. 183-236. In G.A. Slafer (ed.) Genetic improvement of field crops. Marcel Dekker, Inc., New York.

Tollenaar, M., Nissanka, S.P., Aguilera, A., Weise, S.F., \& Swanton, C.J. (1994b). Effect of weed interference and soil nitrogen on four maize hybrids. Agron. J., 86:596-601

Tollenaar, M., Ying, J., \&. Duvick, D.N. (2000). Genetic gain in corn hybrids from the Northern and Central Corn Belt. p. 53-62. In Proc. 55th Corn Sorghum Res. Conf., Chicago. 5-8 Dec. 2000. ASTA, Washington, D.C.

Tollenaar, M., Ahmadzadeh, A., \& Lee, E.A. (2004). Physiological basis of heterosis for grain yield improvement in maize. Crop Sci., 44:2086-2094.

Valero, A., de Juan, Maturano, M., Ramírez, A. A., Tarjuelo Martín-Benito, J. M. \& Ortega Álvarez, J. F. (2005). Growth and nitrogen use efficiency of irrigated maize in a semiarid region as affected by nitrogen fertilization. Spanish Journal of Agricultural Research, (2005) 3(1), 134-144

Ying, J., Lee, E.A., \& Tollenaar, M. (2000). Response of maize leaf photosynthesis to low temperature during the grain-filling period. Field Crops Res., 68:87-96.

Zalba, P., \& Peinemann, N. (1998). Salinity-fertility interactions on early growth of maize (Zea mays L.) and nutrient uptake. Edafologia, 5: 29-39 
Table 1. Season and Era means for seedling emergence characteristics in six maize varieties representing two era of maize breeding in Nigeria (Ilorin, 2005 \& 2006)

\begin{tabular}{|c|c|c|c|}
\hline Season & $\begin{array}{l}\text { Emergence percentage } \\
(\mathrm{E} \%)\end{array}$ & $\begin{array}{l}\text { Emergence index } \\
\text { (EI) }\end{array}$ & $\begin{array}{l}\text { Emergence rate index } \\
\text { (ERI) }\end{array}$ \\
\hline 2005 Late & $58.71 \mathrm{~b}$ & 0.90 & $0.015 b$ \\
\hline 2006 Early & $74.36 \mathrm{a}$ & 0.93 & $0.013 \mathrm{a}$ \\
\hline$S E \pm$ & 0.70 & ns & 0.003 \\
\hline \multicolumn{4}{|l|}{ Era } \\
\hline 1970 's & $63.30 \mathrm{~b}$ & $0.90 \mathrm{~b}$ & 0.013 \\
\hline 1990 's & $69.77 \mathrm{a}$ & $0.94 \mathrm{a}$ & 0.015 \\
\hline$S E+$ & 0.71 & 0.069 & ns \\
\hline \multicolumn{4}{|l|}{$F$-Test } \\
\hline Season (S) & $2938.44 * *$ & 0.013 & $5.2 \times 10^{-5^{*}}$ \\
\hline $\operatorname{Era}(E)$ & $503.37 * *$ & $0.017 *$ & $2.0 \times 10^{-5}$ \\
\hline Genotype/Era $(G / E)$ & $1572.10 * *$ & 0.008 & $2.0 \times 10^{-4 * * *}$ \\
\hline$S x E$ & $482.73 * *$ & $2.9 \times 10^{-3}$ & $1.9 \times 10^{-5}$ \\
\hline$S \times G / E$ & 233.76 & 0.006 & $2.0 \times 10^{-5}$ \\
\hline$\% C V$ & 18.37 & 7.05 & 22.45 \\
\hline
\end{tabular}

*, **; significant F-test at 0.05 and 0.01 levels of probability respectively; Means in a column followed by the same alphabets are not significantly different.

Table 2. Genotypic means for seedling emergence characteristics in six maize varieties representing two era of maize breeding in Nigeria (Ilorin, 2005 \& 2006)

\begin{tabular}{llll}
\hline Genotype & $\begin{array}{l}\text { Emergence percentage } \\
(\mathrm{E} \%)\end{array}$ & $\begin{array}{l}\text { Emergence index } \\
(\mathrm{EI})\end{array}$ & $\begin{array}{l}\text { Emergence rate index } \\
\text { (ERI) }\end{array}$ \\
\hline Era1(1970's) & & & \\
TZPB-SR & $71.96 \mathrm{~b}$ & 0.90 & 0.011 \\
TZB-SR & $69.38 \mathrm{bc}$ & 0.86 & 0.010 \\
ACR 9943DMRSR & $48.56 \mathrm{~d}$ & 0.94 & 0.020 \\
& & & \\
Era 2 (1990's) & & & 0.020 \\
ACR96 DMR LSRW & $52.35 \mathrm{c}$ & 0.92 & 0.014 \\
ACR97TZLCOMP1-W & $77.64 \mathrm{ab}$ & 0.96 & 0.011 \\
ACR99TZLCOMP 4 DMRSR & $79.33 \mathrm{a}$ & 0.93 & 0.014 \\
\hline Mean & 66.54 & 0.92 & $2.0 \times 10^{-2}$ \\
SE & 1.22 & $\mathrm{~ns}$ & \\
\hline
\end{tabular}

Means in a column followed by the same alphabets are not significantly different. 
Table 3. Season and Era means for physiological characteristics in six maize varieties representing two era of maize breeding in Nigeria (Ilorin, 2005 \& 2006)

\begin{tabular}{|c|c|c|c|c|c|c|c|c|}
\hline & \multicolumn{2}{|c|}{$\begin{array}{l}\text { Crop growth rate } \\
\left(\mathrm{gm}^{-2} \mathrm{~d}^{-1}\right)\end{array}$} & \multicolumn{2}{|c|}{$\begin{array}{l}\text { Relative growth rate } \\
\left(\mathrm{gkg}^{-1} \mathrm{day}^{-1}\right)\end{array}$} & \multicolumn{2}{|c|}{$\begin{array}{l}\text { Net assimilation rate } \\
\left(\mathrm{g} \mathrm{cm}^{-2} \text { day }^{-1}\right)\end{array}$} & \multicolumn{2}{|c|}{$\begin{array}{l}\text { Leaf area ratio } \\
\left(\mathrm{m}^{2} \mathrm{~m}^{-2}\right)\end{array}$} \\
\hline & 42DAP & 56DAP & 42DAP & 56DAP & 42DAP & 56DAP & 42DAP & 56DAP \\
\hline \multicolumn{9}{|l|}{ Season } \\
\hline 2005 Late & $12.73 a$ & $37.40 \mathrm{a}$ & $0.11 \mathrm{~b}$ & $0.01 \mathrm{~b}$ & $0.036 \mathrm{a}$ & 0.08 & $3.16 \mathrm{~b}$ & $1.37 \mathrm{~b}$ \\
\hline 2006 Early & $7.3 b$ & $31.79 b$ & $0.13 \mathrm{a}$ & $0.11 \mathrm{a}$ & $0.027 \mathrm{~b}$ & 0.07 & $5.01 \mathrm{a}$ & $1.80 \mathrm{a}$ \\
\hline$S E \pm$ & 0.36 & 0.57 & Ns & $3.2 \times 10^{2}$ & $2.1 \times 10^{2}$ & Ns & 0.18 & 0.12 \\
\hline \multicolumn{9}{|l|}{ Era } \\
\hline 1970 's & 10.37 & 32.25 & 0.12 & 0.01 & 0.033 & 0.080 & $3.96 \mathrm{~b}$ & 1.60 \\
\hline 1990 's & 9.66 & 36.94 & 0.12 & 0.01 & 0.028 & 0.069 & $4.21 \mathrm{a}$ & 1.57 \\
\hline$S E \pm$ & ns & 0.57 & ns & ns & ns & ns & 0.18 & ns \\
\hline \multicolumn{9}{|l|}{ F-Test } \\
\hline Season (S) & $352.35^{* *}$ & $376.99 *$ & $\begin{array}{l}4.6 \mathrm{x} \\
10^{-3} *\end{array}$ & $5.2 \times 10^{-3 * *}$ & $8.3 \times 10^{-4 * *}$ & $1.3 \times 10^{-3}$ & $41.29^{*}$ & $2.15^{*}$ \\
\hline $\operatorname{Era}(E)$ & 304.35 & $264.70^{*}$ & $\begin{array}{l}2.1 \mathrm{x} \\
10^{-6}\end{array}$ & 0.005 & $3.0 \times 10^{-4}$ & $1.5 \times 10^{-3}$ & $0.73 *$ & $6.3 \times 10^{-3}$ \\
\hline \multicolumn{9}{|c|}{ Genotype/Era } \\
\hline$(G / E)$ & 11.38 & 319.70 & $\begin{array}{l}1.9 \mathrm{x} \\
10^{-3}\end{array}$ & $3.0 \times 10^{-3} * *$ & $1.0 \times 10^{-4 * *}$ & $3.3 \times 10^{-4}$ & 0.05 & 0.30 \\
\hline$S \times E$ & 3.87 & 489.47 & $\begin{array}{l}1.0 \mathrm{x} \\
10^{-4}\end{array}$ & $2.7 \times 10^{-4^{* *}}$ & 0.0 & $1.7 \times 10^{-4 * *}$ & 1.25 & 0.03 \\
\hline$S \times G / E$ & 1.08 & 72.21 & $\begin{array}{l}1.0 \mathrm{x} \\
10^{-4}\end{array}$ & $1.1 \times 10^{-3}$ & $1.1 \times 10^{-5}$ & $3.5 \times 10^{-4}$ & 0.19 & 0.33 \\
\hline$\% C V$ & 30.46 & 22.27 & 26.47 & 34.44 & 33.23 & 32.75 & 19.57 & 22.06 \\
\hline
\end{tabular}

*, **; Significant F-test at 0.05 and 0.01 levels of probability respectively; DAP =Days after planting. Means in a column followed by the same alphabets are not significantly different. 
Table 4. Genotypic means for physiological characteristics in six maize varieties representing two era of maize breeding in Nigeria (Ilorin, 2005 \& 2006)

\begin{tabular}{|c|c|c|c|c|c|c|c|c|}
\hline \multirow[b]{2}{*}{ Genotype } & \multicolumn{2}{|c|}{$\begin{array}{l}\text { Crop growth rate } \\
\left(\mathrm{gm}^{-2} \mathrm{~d}^{-1}\right)\end{array}$} & \multicolumn{2}{|c|}{$\begin{array}{l}\text { Relative growth } \\
\operatorname{rate}\left(\mathrm{gkg}^{-1} \text { day }^{-1}\right)\end{array}$} & \multicolumn{2}{|c|}{$\begin{array}{l}\text { Net assimilation rate(g } \\
\left.\mathrm{cm}^{-} 2 \text { day }^{-1}\right)\end{array}$} & \multicolumn{2}{|c|}{$\begin{array}{l}\text { Leaf area ratio } \\
\left(\mathrm{m}^{2} \mathrm{~m}^{-2}\right)\end{array}$} \\
\hline & 42DAP & 56DAP & 42DAP & 56DAP & 42DAP & 56DAP & 42DAP & 56DAP \\
\hline
\end{tabular}

$\operatorname{Eral}(1970$ 's)

$\begin{array}{lllllllll}T Z P B-S R & 10.28 \mathrm{ab} & 28.29 \mathrm{c} & 0.118 \mathrm{a} & 0.109 & 0.034 & 0.079 & 3.956 & 1.606 \mathrm{a} \\ T Z B-S R & 9.22 \mathrm{~b} & 27.05 \mathrm{~d} & 0.106 \mathrm{a} & 0.093 & 0.030 & 0.074 & 3.928 & 1.848 \mathrm{a} \\ \text { ACR 9943DMRSR } & 11.63 \mathrm{a} & 41.40 \mathrm{a} & 0.124 \mathrm{a} & 0.098 & 0.036 & 0.088 & 4.004 & 1.333 \mathrm{~b}\end{array}$

Era 2 (1990's)

\begin{tabular}{|c|c|c|c|c|c|c|c|c|}
\hline ACR96 DMR LSRW & $9.71 \mathrm{~b}$ & $41.12 \mathrm{a}$ & $0.125 \mathrm{a}$ & 0.103 & 0.031 & 0.075 & 4.269 & $1.631 \mathrm{a}$ \\
\hline ACR97TZLCOMP1-W & $10.81 \mathrm{ab}$ & $36.78 \mathrm{ab}$ & $0.129 \mathrm{a}$ & 0.098 & 0.030 & 0.064 & 4.093 & $1.469 \mathrm{~b}$ \\
\hline \multicolumn{9}{|l|}{ ACR99TZLCOMP 4} \\
\hline$D M R S R$ & $8.45 \mathrm{c}$ & $32.94 \mathrm{ab}$ & $0.093 b$ & 0.098 & 0.024 & 0.068 & 4.264 & $1.618 \mathrm{a}$ \\
\hline Mean & 10.02 & 34.54 & 0.116 & 0.10 & 0.031 & 0.075 & 4.01 & 1.58 \\
\hline$S E \pm$ & 0.63 & 0.98 & $6.3 \times 10^{-2}$ & ns & ns & ns & $\mathrm{ns}$ & 0.22 \\
\hline
\end{tabular}

Means in a column followed by the same alphabets are not significantly different.

Table 5. Season and Era means for days to flowering, grain yield and yield components in six maize varieties representing two era of maize breeding in Nigeria (Ilorin, 2005 \& 2006)

\begin{tabular}{|c|c|c|c|c|c|c|c|c|c|c|c|}
\hline Season & $\begin{array}{l}\text { Days to } \\
\text { anthesis } \\
\text { (days) }\end{array}$ & $\begin{array}{l}\text { Days to } \\
\text { silking } \\
\text { (days) }\end{array}$ & $\begin{array}{l}\text { Anthesis-silking-interval } \\
\text { (days) }\end{array}$ & $\begin{array}{l}\text { Ear } \\
\text { height } \\
(\mathrm{cm})\end{array}$ & $\begin{array}{l}\text { Tassel } \\
\text { branch } \\
\text { number } \\
\text { (no) }\end{array}$ & $\begin{array}{l}\text { Cob } \\
\text { diameter } \\
(\mathrm{cm})\end{array}$ & $\begin{array}{l}\text { Cob } \\
\text { length } \\
(\mathrm{cm})\end{array}$ & $\begin{array}{l}300 \\
\text { Kernel } \\
\text { weight } \\
(\mathrm{gm})\end{array}$ & $\begin{array}{l}\text { Kernel } \\
\text { depth } \\
(\mathrm{cm})\end{array}$ & $\begin{array}{l}\text { Kernel } \\
\text { row } \\
\text { number } \\
\text { (no) }\end{array}$ & $\begin{array}{l}\text { Grain } \\
\text { yield } \\
\left(\mathrm{t} / \mathrm{ha}^{-1}\right)\end{array}$ \\
\hline 2005 Late & 62 & 63 & 1 & 73.37 & 19 & 14 & 18.13 & 4.9 & 77.48 & 15 & 1.73 \\
\hline \multicolumn{12}{|l|}{ Era } \\
\hline 1970 's & 63 & 65 & 2 & 74.41 & 19 & 14.41 & 17.90 & 5.00 & 84.20 & 14 & 1.83 \\
\hline 1990 's & 63 & 65 & 2 & 72.29 & 17 & 14.15 & 18.37 & 4.57 & 80.41 & 15 & 1.93 \\
\hline$S E \pm$ & ns & ns & ns & 0.71 & 0.42 & 0.17 & 0.22 & 0.18 & 0.75 & $\mathrm{~ns}$ & $\mathrm{~ns}$ \\
\hline $\operatorname{Era}(E)$ & $3.05^{*}$ & 0.08 & 0.19 & 53.93 & 42.19 & 0.74 & 2.61 & 2.28 & $173.20 *$ & 1.7 & 0.28 \\
\hline \multicolumn{12}{|c|}{ Genotype/Era } \\
\hline$(G / E)$ & 3.73 & 3.79 & 0.13 & 138.35 & 70.35 & 0.32 & 1.05 & 0.19 & 346.58 & 5.19 & $0.35^{*}$ \\
\hline$S x E$ & 7.52 & 3.00 & 1.02 & 194.89 & 1.02 & 0.07 & 0.00 & 0.49 & 0.60 & 11.02 & 0.05 \\
\hline$S \times G / E$ & 2.15 & 1.79 & 0.29 & 43.86 & 0.40 & 1.41 & 0.00 & 0.75 & 388.30 & 3.35 & 0.01 \\
\hline$\% C V$ & 1.86 & 1.61 & 32.93 & 16.54 & 23.04 & 4.01 & 6.39 & 10.78 & 16.54 & 8.76 & 18.18 \\
\hline
\end{tabular}


Table 6. Genotypic means for days to flowering, grain yield and yield components in six maize varieties representing two era of maize breeding in Nigeria (Ilorin, 2005 \& 2006)

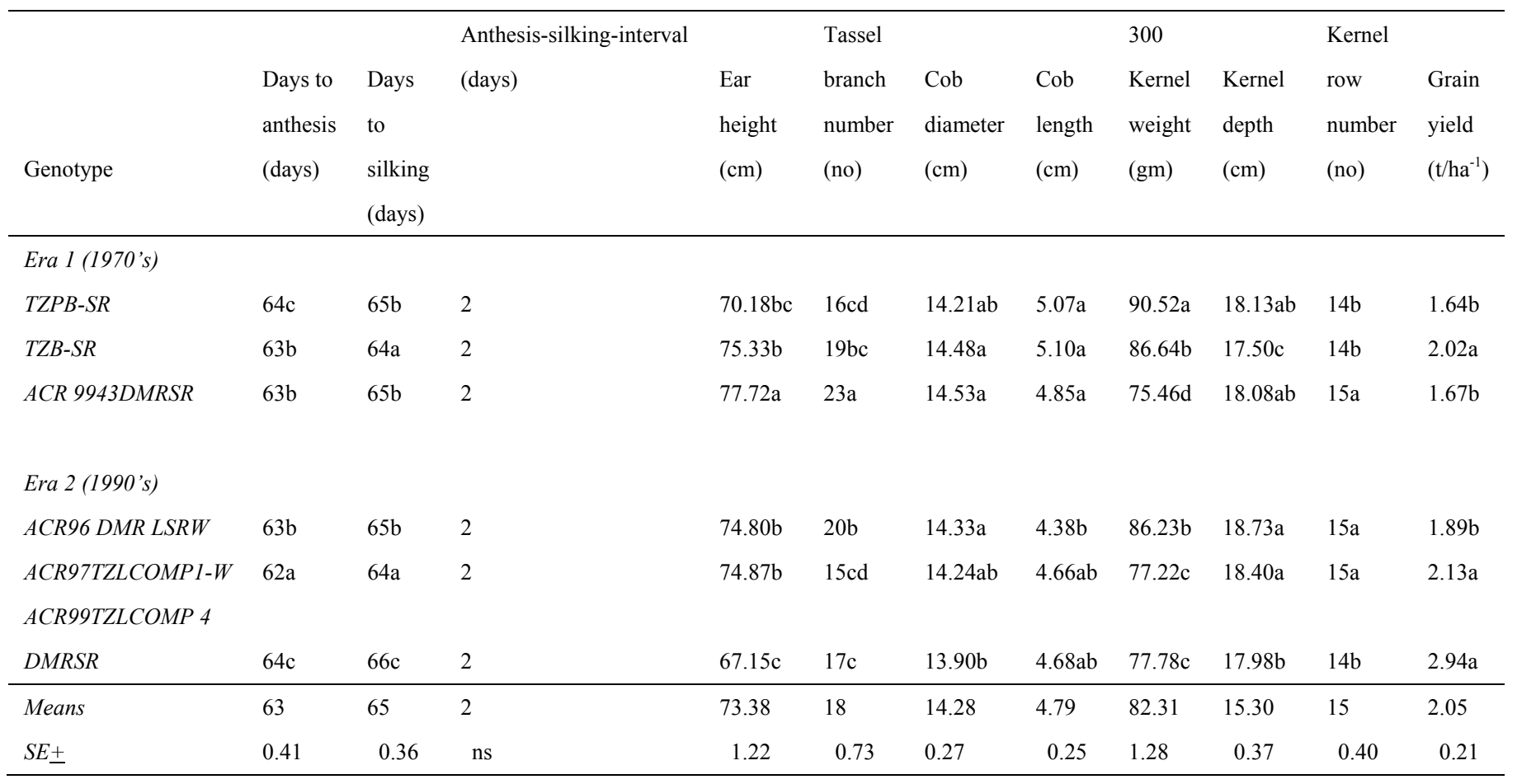

Means in a column followed by the same alphabets are not significantly different. 